\title{
Working
}

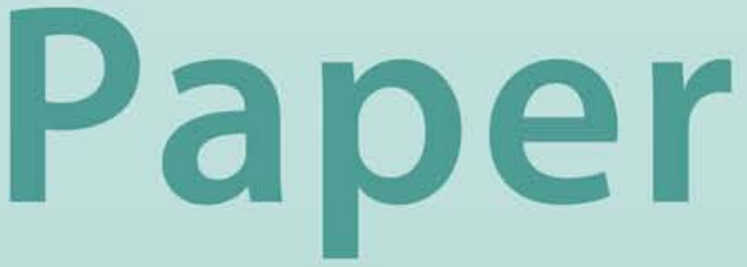


The Use of Credit Ceilings in the Presence of Indirect Monetary Instruments: An Analytical Framework

Plamen Yossifov 


\title{
IMF Working Paper
}

\section{Monetary and Exchange Affairs Department \\ The Use of Credit Ceilings in the Presence of Indirect Monetary Instruments: An Analytical Framework}

\author{
Prepared by Plamen Yossifov ${ }^{1}$ \\ Authorized for distribution by Abdessatar Ouanes
}

December 2002

\begin{abstract}
The views expressed in this Working Paper are those of the author(s) and do not necessarily represent those of the IMF or IMF policy. Working Papers describe research in progress by the author(s) and are published to elicit comments and to further debate.
\end{abstract}

In this paper, we introduce credit ceilings in the standard model of the money multiplier and analyze their role in central bank's management of money supply in the presence of indirect monetary instruments. We show that under a regime of total credit ceilings, their optimal value equals the desired growth rate of the adjusted monetary base. Under a regime of partial credit ceilings, their optimal value depends on the desired growth rate of the adjusted monetary base, the degree of substitutability between the regulated and unregulated types of banks' earning assets, and the autonomous growth rate of the latter.

JEL Classification Numbers:E51, E52

Keywords: credit ceilings, selective credit controls

Author's E-Mail Address:pyossifov@imf,org

\footnotetext{
${ }^{1}$ This paper is based on my master's thesis at the University of Delaware. I would like to thank Dr. Jeffrey Miller for steering my interest on this topic. I also thank him and Dr. James Butkiewicz for insightful comments on earlier drafts of the paper. Any remaining errors are author's sole responsibility.
} 


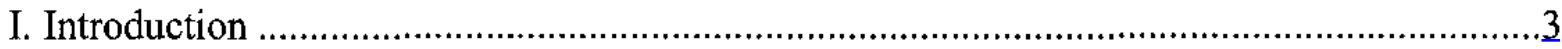

II. The Money Multiplier and Credit Ceilings …..............................................................

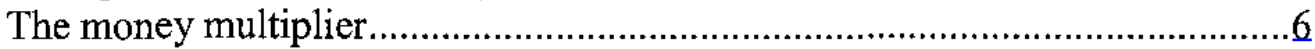

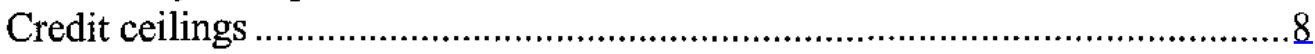

III. Issues Related to Central Banks' Joint Use of Credit Ceilings and Indirect Monetary

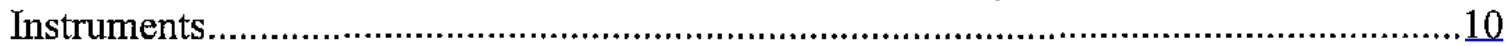

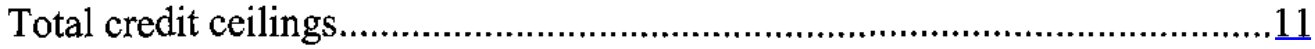

Partial credit ceilings..............................................................................

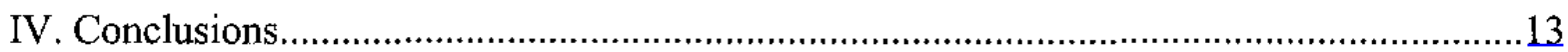

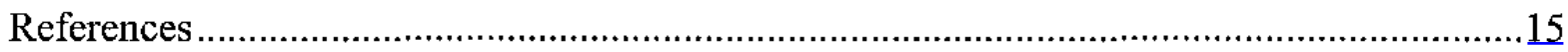

Text Tables

1. Use of Credit Ceilings in Transitional Countries, 1990-1994 ........................................ 


\section{INTRODUCTION}

Credit ceilings are one of the most commonly used forms of selective credit controls. ${ }^{2}$ A credit ceiling is the maximum allowed percentage increase of the stock of prespecified types of bank assets over a given time period. Its value is usually set in reference to the stock of the regulated assets at the end of some base period (Farahbaksh and Sensenbrenner, 1996, p. 5). By manipulating the modalities of their design, credit ceilings can be used by central banks for a variety of purposes (e.g., targeting of monetary aggregates, enforcement of prudential rules, channeling of credit to specific sectors of the economy, etc.) (Hilbers, 1993, p. 3). In this paper, we analyze the role of credit ceilings as instruments of monetary policy.

The economic rationale for the use of credit ceilings as a monetary policy instrument stems from the ex post identity between the stock of the domestic currency component of broad money (i.e., M2) and the sum of the stocks of the adjusted monetary base (i.e., monetary base minus banks' borrowed reserves from the central bank) and banks' domestic currency earning assets (Brunner and Meltzer, 1968, p. 31). The intuition behind this identity is that money can be created by either the central or commercial banks. "Monetary control, therefore, must be implemented through operating on the lending activities of both the central bank and the commercial banks." (Simmons, 1947, p. 634). The imposition of credit ceilings impedes commercial banks' ability to create money, by limiting the amount of funds channeled to the rest of the economy via banks' acquisition of regulated assets.

Credit ceilings have been used extensively in the past in industrial countries, such as Belgium, Denmark, France, Italy, Netherlands, Norway, Portugal, and the United Kingdom, and in developing countries, including Egypt, Guyana, Jamaica, Kenya, and Madagascar (Farahbaksh and Sensenbrenner, 1996). In the early 1990's, there was a resurgence in interest in credit ceilings by policymakers and economists alike, as Central and Eastern European (CEE) countries and the countries of the former Soviet Union (FSU) embarked on their transition from centrally planned to market economies. Between 1990 and 1994, 14 out of 25 $\mathrm{CEE}$ and FSU countries have used credit ceilings for an average of 1.6 years (Table 1).

Despite the history of widespread use of credit ceilings in the conduct of monetary policy, "professional economic literature is devoid of any general theory of credit and credit controls as instruments of public policy" (Hodgman, 1972, p. 343). The state of knowledge in this field has changed little since then, as most of the research on credit ceilings done in the early 1990s focuses on the operational issues of their implementation and is descriptive in nature (Bredenkamp, 1993; Hilbers, 1993; Mathieson and Haas, 1994; Farahbaksh and Sensenbrenner, 1996). In this paper, we present a simple analytical framework that allows us to examine the role of credit ceilings in central bank's management of money supply, with a particular emphasis on the need for coordination of the setting of their values and those of the indirect monetary instruments used by the central bank. The special attention paid on the

${ }^{2}$ Selective credit controls encompass all instruments used by central banks to influence directly the flows of credit in the economy (Hodgman, 1972). 
interaction of credit ceilings with indirect instruments of monetary control is motivated by the fact that the vast majority of countries that have used credit ceilings have simultaneously relied on one or more indirect monetary instruments (13 out of $14 \mathrm{CEE}$ and FSU countries as shown in Table 1). The interaction between credit ceilings and indirect monetary instruments has been noted in previous studies of credit controls (Davis, 1971, p. 72), but to our knowledge it has not been analyzed within a coherent analytical framework.

Our approach is to introduce credit ceilings in the standard model of the money multiplier and analyze the implications this has on the model's results. There are two reasons for choosing such an approach. On the one hand, the link between credit ceilings and the money multiplier has been discussed in the existing literature though it has not been formally modeled:

\footnotetext{
"In these economies, ceilings were often seen as an alternative to the immediate shift to more market-oriented instruments of monetary policy and reliance on reserve money management. Making such a shift at that time posed high risk of loss of control because the transmission mechanisms were largely unknown. In particular, money multipliers were showing signs of erratic behavior due to structural breakdowns." (Farahbaksh and Sensenbrenner, 1996, p. 4).

"If the supply of base money is controlled, the cash-deposit ratio is stable, reserve requirements are enforced and there are no excess reserves, growth in total credit within a given period is fully determined. A rationale for administrative credit ceilings, in addition to reserve requirements, arises only in the case where there are excess reserves in the system and the reserve money multiplier is unstable." (Bredenkamp, 1993, p. 15).
}

On the other hand, it is apparent from the definition of credit ceilings that they can only be used within a framework of monetary policy based on targeting of a monetary or credit aggregate. The money supply process under such policy regimes has been traditionally analyzed within the framework of the standard model of the money multiplier (Brunner and Meltzer, 1964; Rasche, 1993). 
Table 1. Use of Credit Ceilings in Transitional Countries, 1990-1994

\begin{tabular}{|c|c|c|c|c|c|c|c|}
\hline & $\begin{array}{l}\text { Years of use of } \\
\text { credit ceilings }\end{array}$ & $\begin{array}{l}\text { Years of joint use of } \\
\text { credit ceilings and } \\
\text { indirect instruments }\end{array}$ & 1990 & 1991 & 1992 & 1993 & 1994 \\
\hline \multicolumn{8}{|l|}{$C E E$ countries } \\
\hline Albania & 3 & 3 & & & $\mathrm{X}$ & $\mathrm{X}$ & $\mathrm{X}$ \\
\hline Bulgaria & 3 & 3 & & $\mathrm{X}$ & $\mathrm{X}$ & $\mathrm{X}$ & \\
\hline Croatia ${ }^{2} /$ & 1 & 1 & $\mathrm{X}$ & & & & \\
\hline Czech Republic ${ }^{2}$ & 1 & 1 & & $\mathrm{X}$ & & & \\
\hline Hungary & 2 & 2 & $\mathrm{X}$ & $\mathrm{X}$ & & & \\
\hline Macedonia, FYR 2 & 2 & 2 & $\mathrm{X}$ & & & & $X$ \\
\hline Poland & 3 & 3 & $\mathrm{X}$ & $\mathrm{X}$ & $\mathrm{X}$ & & \\
\hline Romania & 1 & 0 & & $\mathrm{X}$ & & & \\
\hline Slovak Republic $\underline{\underline{2}}$ & 2 & 2 & & $\mathrm{X}$ & & $\mathrm{X}$ & \\
\hline Slovenia $\underline{2}$ & 1 & 1 & & $\mathrm{X}$ & & & \\
\hline \multicolumn{8}{|l|}{ FSU countries } \\
\hline Armenia & 0 & 0 & - & & & & \\
\hline Azerbaijan & 0 & 0 & - & & & & \\
\hline Belarus & 0 & 0 & - & & & & \\
\hline Estonia & 0 & 0 & - & & & & \\
\hline Georgia & 1 & 1 & - & & $\mathrm{X}$ & & \\
\hline Kazakhstan & 0 & 0 & - & & & & \\
\hline Kyrgyz Republic & 1 & 1 & - & & & & $\mathrm{X}$ \\
\hline Latvia & 0 & 0 & - & & & & \\
\hline Lithuania & 1 & 1 & - & & $\mathrm{X}$ & & \\
\hline Moldova & 0 & 0 & - & & & & \\
\hline Russia & 0 & 0 & - & & & & \\
\hline Tajikistan & 0 & 0 & - & & & & \\
\hline Turkmenistan & 0 & 0 & - & & & & \\
\hline Ukraine & 1 & 1 & - & & & & $\mathrm{X}$ \\
\hline Uzbekistan & 0 & 0 & - & & & & \\
\hline
\end{tabular}

Source: De Melo and Denizer (1997).

Note: The transition from centrally planned to market economies commenced in 1989 in most CEE countries and in 1991 in FSU countrics.

${ }^{1 /}$ Including one or more of the following: (1) reserve requirements; (2) refinancing/credit auction; (3) open market opcrations with treasury bills or central bank bills.

2/ Instrument use shown for Czechoslovakia and Yugoslavia, as appropriate, prior to breakup. 


\section{The Money Multiplier and Credit Ceilings}

\section{The money multiplier}

The stock of the domestic currency component of broad money equals the sum of the stocks of the adjusted monetary base and banks' domestic currency earning assets ${ }^{3}$ (Brunner and Meltzer, 1968, p. 31):

$$
\begin{gathered}
M_{t} \equiv B_{t}+E A_{t} \text {, where } \\
M_{t} \text { - the stock of broad money (M2) at the end of period (t). } \\
\text { Equals the sum of the stocks of currency outside banks, } \\
\text { demand, savings, and time deposits. } \\
B_{t} \text { - the stock of the adjusted monetary base at the end of } \\
\text { period (t). Equals the monetary base minus banks' } \\
\text { borrowed reserves from the central bank. } \\
E A_{t} \text { - the stock of banks' total earning assets at the end of } \\
\text { period (t). }
\end{gathered}
$$

The above identity is based on a simplified representation of the balance sheets of the central bank and commercial banks that assumes away many balance sheet items, such as capital accounts and net foreign assets. In practical implementations of this analytical framework, equation [1] would need to be adjusted to reflect more realistically the stylized balance sheets of the central bank and commercial banks in the particular country (for the case of the United States, see Mishkin, 1997, pp. 227 and 416). To cast our analysis in terms of the money multiplier, we divide both sides of equation [1] by the stock of the adjusted monetary base at the end of period $(\mathrm{t})$ :

$$
\begin{aligned}
& m_{t} \equiv 1+\frac{E A_{t}}{B_{t}}, \text { where } \\
& m_{t} \equiv \frac{M_{t}}{B_{t}}-\text { the value of the money multiplier at the end of } \\
& \quad \operatorname{period}(\mathrm{t})
\end{aligned}
$$

The logarithmic transformation of equation [2] expressed in first differences allows us to analyze it in terms of growth rates of the participating variables. ${ }^{4}$ The growth rate of the

\footnotetext{
${ }^{3}$ Throughout the text, all references to money and credit aggregates refer to their domestic currency components even when not explicitly specified.

${ }^{4}$ To derive expression [3], we first take logs of both sides of equation [2] and apply a firstdifference operator $\left(\Delta X_{t}=X_{t}-X_{t-1}\right): \ln \left(m_{t}-1\right)-\ln \left(m_{t-1}-1\right) \equiv\left[\ln E A_{t}-\ln E A_{t-1}\right]-\left[\ln B_{t}-\ln B_{t-1}\right]$.
} 
money multiplier in a given period is proportional to the difference between the growth rates of banks' earning assets and the adjusted monetary base, with a factor of proportionality $(\gamma)$ less than unity:

$$
\begin{gathered}
\frac{\Delta m_{t}}{m_{t-1}}=\gamma_{t-1} \cdot\left[\frac{\Delta E A_{t}}{E A_{t-1}}-\frac{\Delta B_{i}}{B_{t-1}}\right], \text { where } \\
\gamma_{t-1}=\frac{m_{t-1}-1}{m_{t-1}}<1
\end{gathered}
$$

\section{The standard model of the money multiplier}

The standard model of the money multiplier postulates the existence of intertemporary stable statistical relationship between the stock of high-powered money and the money supply called the money multiplier (Brunner and Meltzer, 1964, p. 252; Rasche, 1993):

$$
\begin{aligned}
& M_{t}=\mathrm{m} \cdot B_{t} \text { where } \\
& \qquad \mathrm{m}=m_{t}=m_{t-1} \text { or } \frac{\Delta m_{t}}{m_{t-1}}=0
\end{aligned}
$$

The key assumptions of this theory are that economic agents (the public and the banking sector) have desired structures of their portfolios which remain unaffected by central bank's manipulations of the adjusted monetary base and that economic agents' actual asset holdings are always equal to the desired (Rasche, 1993, p. 31). The stock of high-powered money consists entirely of items included in the liability side of central bank's balance sheet. According to the standard model, monetary authorities can effectively target the growth of the money supply and credit by manipulating the size of these liabilities and using the behaviorally determined value of the money multiplier to forecast the resulting changes in the quantity of money and credit (from [1] and [4]):

We then approximate the terms in that equation with the following expressions:

$\ln \left(m_{t}-1\right)-\ln \left(m_{t-1}-1\right) \approx \frac{\Delta m_{t}}{m_{t-1}-1} ; \ln E A_{t}-\ln E A_{t-1} \approx \frac{\Delta E A_{t}}{E A_{t-1}} ;$ and $\ln B_{t}-\ln B_{t-1} \approx \frac{\Delta B_{t}}{B_{t-1}}$

(McCallum, 1989, p.112). We then assume that the approximation errors are negligible, which can be assured by shortening the length of the time period to decrease the absolute value of the growth rates. This allows us to treat the result as equality, the left-hand side of which we can multiply by $\frac{m_{t-1}}{m_{t-1}}$ and regroup. 


$$
\begin{aligned}
\Delta M_{t}= & \mathrm{m} \cdot \Delta B_{t}^{d} \\
\Delta E A_{t}= & (\mathrm{m}-1) \cdot \Delta B_{t}^{d}, \text { where } \\
& \Delta B_{t}^{d}-\text { desired expansion/contraction of the adjusted monetary } \\
& \text { base in period (t), which is fully determined by the } \\
& \text { setting of the indirect monetary instruments. } \\
& (\mathrm{m}-1)-\text { banks' earning-asset multiplier (Brunner and Meltzer, } \\
& 1968, \text { p. } 32) .
\end{aligned}
$$

\section{Credit ceilings}

A credit ceiling is the maximum allowed percentage increase of the stock of prespecified types of bank assets over a given time period. Its value is usually set in reference to the stock of the regulated assets at the end of some base period (Farahbaksh and Sensenbrenner, 1996, p. 5$):^{5}$

$$
\begin{gathered}
c c_{t} \equiv \frac{\Delta R E A_{t}}{R E A_{t-1}} \cdot 100, \text { where } \\
\qquad c_{t}-\text { the percentage value of the credit ceiling in period }(\mathrm{t}) . \\
\Delta R E A_{t}-\text { the maximum allowed net increase of the stock of } \\
\text { the regulated banks' earning assets in period }(\mathrm{t}) . \\
R E A_{t-1} \text { - the reference value of the stock of regulated banks' } \\
\text { earning assets at the end of the base period. }
\end{gathered}
$$

The imposition of quantitative controls makes sense only if they force banks to acquire less of the regulated assets than otherwise desired. This, in conjunction with the assumed profit-maximizing behavior of banks, will result in complete utilization of the credit ceilings. Thus, we can define $\triangle R E A_{t}$ as the realized value of the net increase of the stock of the regulated banks' earning assets in period $(\mathrm{t})$. There are two types of credit ceilings depending on the scope of the regulated banks' earning assets: total and partial credit ceilings. Total credit ceilings limit the rate of growth of all banks' earning assets. Partial credit ceilings limit the rate of growth of only selected types of banks' earning assets.

\footnotetext{
${ }^{5}$ To simplify the notation, we assume without loss of generality that the base period is the one preceding the period in which the credit ceilings apply.
} 


\section{The money multiplier under a regime of total credit ceilings}

Total credit ceilings limit the rate of growth of all banks' earning assets $\left(\frac{c c_{t}}{100} \equiv \frac{\Delta R E A_{t}}{R E A_{t-1}}=\frac{\Delta E A_{t}}{E A_{t-1}}\right)$. Under a regime of total credit ceilings, the growth rate of the money multiplier equals (from [3]):

$$
\frac{\Delta m_{t}}{m_{t-1}}=\gamma_{t-1} \cdot\left[\frac{c c_{t}}{100}-\frac{\Delta B_{t}}{B_{t-1}}\right]
$$

\section{The money multiplier under a regime of partial credit ceilings}

Partial credit ceilings limit the rate of growth of only selected types of banks' earning assets. Banks' total earning assets $(E A)$ would then equal the sum of their regulated and unregulated components:

$$
\begin{aligned}
& E A_{t}=R E A_{t}+U E A_{t} \\
& \frac{\Delta E A_{t}}{E A_{t-1}}=\beta_{t-1} \cdot \frac{\Delta R E A_{t}}{R E A_{t-1}}+\left(1-\beta_{t-1}\right) \cdot \frac{\Delta U E A_{t}}{U E A_{t-1}}, \text { where }
\end{aligned}
$$

$U E A_{t}$ - the stock of banks' earning assets that are not subject to credit ceilings at the end of period ( $t)$.

$$
\begin{array}{r}
\beta_{t-1}=\frac{R E A_{t-1}}{E A_{t-1}}<1-\text { the share of regulated banks' earning } \\
\text { assets at the end of period (t-1). }
\end{array}
$$

Depending on banks' portfolio allocation strategy, the regulated and unregulated types of banks' earning assets can be substitutes (perfect or imperfect) or complements (perfect or imperfect) (Khatkhate and Villanueva, 1980, pp. 598-99). To capture this idea, we decompose the growth rate of banks' unregulated earning assets as follows:

$$
\begin{aligned}
& \frac{\Delta U E A_{t}}{U E A_{t-1}}=\alpha \cdot \frac{R E A_{t-1}}{U E A_{t-1}} \cdot \frac{\Delta R E A_{t}}{R E A_{t-1}}+\delta_{t}, \text { where } \\
&-1 \leq \alpha \leq 1-\text { degree of substitutability/complementarity } \text { between the regulated and unregulated types of } \\
& \text { banks' earning assets. }
\end{aligned}
$$


assets independent from banks' investments in regulated assets.

By construction, the coefficient $(\alpha)$ measures the absolute change in the size of the unregulated types of banks' earning assets in response to a one unit increase/decrease in the size of the regulated banks' earning assets. ${ }^{6}$ If $\alpha=-1$, the regulated and unregulated types of banks' earning assets are perfect substitutes, whereas if $\alpha=1$, they are perfect complements. The growth rate of the unregulated types of banks' earning assets independent from banks' investments in regulated assets $\left(\delta_{t}\right)$ can be a constant or itself a function of other explanatory variables, in which case its value can be obtained from a preferred regression model.

We can now substitute [7], [9], and [10] in [3] to arrive at the final expression of the growth rate of the money multiplier in the presence of partial credit ceilings:

$$
\frac{\Delta m_{t}}{m_{t-1}}=\gamma_{t-1} \cdot\left[\beta_{t-1} \cdot(1+\alpha) \cdot \frac{c c_{t}}{100}+\left(1-\beta_{t-1}\right) \cdot \delta_{t}-\frac{\Delta B_{t}}{B_{t-1}}\right]
$$

\section{Issues Related to Central Banks' JoInt Use of CRedit Ceilings and INDIRECT MONETARY INSTRUMENTS}

It can easily be seen from [8] and [11] that in the absence of coordination between the setting of the values of indirect monetary instruments and credit ceilings, the latter can impede the process of multiple deposit creation and hence affect the value of the money multiplier:

\footnotetext{
"In particular, the existence of the bank credit ceiling would inhibit - although not preclude the use of orthodox instruments to promote monetary expansion. The Federal Reserve could still engage in expansionary open market purchases. However, the excess reserves created in the process could not be used for further deposit cxpansion, since any such expansion could be set in motion only by increased bank lending and investing in violation of the credit ceiling. This means, in effect, that the Federal Reserve would be able to expand deposits only one dollar for each dollar of reserve expansion. No "multiple expansion" of deposits would be possible."

(Davis, 1971, p. 72).
}

This, however, will no longer be the case if the central bank deliberately coordinates the setting of the values of indirect monetary instruments and credit ceilings to preserve the constancy of the money multiplier. Under such a strategy, the constancy of the money multiplier will ensure that the results from the standard model of the money multiplier, discused above, remain valid.

${ }^{6}$ To see that multiply both sides of [10] by $U E A_{t-1}$. 
In the remainder of this section, we derive rules for setting of the values of total and partial credit ceilings that will ensure the constancy of the money multiplier. Adherence to these rules will stabilize the value of the money multiplier, in the sense that it will create an upward bound, which the money multiplier can not exceed. Thus, positive shocks in liquidity preferences of households and firms will have no effect on monetary outcomes. Negative shocks, on the other hand, can result in underutilization of the credit ceilings, in which case the central bank will undershoot its monetary or credit target. This is likely to be less of a concern to central banks that resort to credit ceilings, the latter being hard-line instruments for containing the growth of monetary and credit aggregates. In what follows, we assume that at the beginning of each period central banks adjust the settings of the indirect instruments of monetary control to achieve the desired rate of growth of the adjusted monetary base and then set the value of the credit ceilings so that the rate of growth of the money multiplier over the period is equal to zero. The practical relevancy of our analysis is implicitly supported by the observation made by Bredenkamp (1993) and Farahbaksh and Sensenbrenner (1996) that credit ceilings are adopted in countries in which the money multipliers are unstable.

\section{Total credit ceilings}

$$
\text { Under a regime of total credit ceilings }\left(\frac{c c_{t}}{100} \equiv \frac{\Delta R E A_{t}}{R E A_{t-1}}=\frac{\Delta E A_{t}}{E A_{t-1}}\right) \text {, central banks can }
$$

ensure the stability of the money multiplier $\left(\frac{\Delta m_{t}}{m_{t-1}}=0\right)$ and hence the meeting of their

monetary or credit targets, as per [5] or [6], respectively, by setting the value of the credit ceilings to be equal to the desired growth rate of the adjusted monetary base over the period (from equation [3]):

$$
\frac{c c_{t}}{100}=\frac{\Delta B_{t}^{d}}{B_{t-1}}
$$

\section{Partial credit ceilings}

Under a regime of partial credit ceilings, a central bank's ability to stabilize the value of the money multiplier and hence ensure the meeting of its monetary or credit targets depends crucially on the choice of assets left out of the scope of the quantitative controls. If the regulated and unregulated types of banks' earning assets are perfect substitutes (i.e., $\alpha=-1$ ), the imposition of partial credit ceilings will have no effect on the money supply (from equation [11]). In this case, the partial credit restrictions will change the channels through which money flows from the banking sector to the rest of the economy, but not the size of the resulting pool of banks' earning assets. If on the other hand $\alpha \neq-1$, under a regime of partial credit ceilings $\left(\beta_{t-1} \neq 1\right)$, the central bank can ensure the stability of the 
money multiplier $\left(\frac{\Delta m_{t}}{m_{t-1}}=0\right)$ by setting the value of the credit ceilings as follows (from equation [11]):

$$
\frac{c c_{t}}{100}=\frac{1}{\beta_{t-1} \cdot(1+\alpha)} \cdot\left[\frac{\Delta B_{t}^{d}}{B_{t-1}}-\left(1-\beta_{t-1}\right) \cdot \delta_{t}\right], \text { where } \alpha \neq-1
$$

In this case, the effectiveness of credit ceilings in stabilizing the value of the money multiplier hinges on the central bank's ability to correctly predict the rate of growth of the unregulated types of banks' earning assets that is independent from banks' investments in regulated assets $\left(\delta_{t}\right)$. One way the central bank can ensure this is by leaving outside the scope of the credit ceilings only assets, for which the supply is relatively exogenous and easy to predict. For example, in the case of Bulgaria, over the period January 1991 - June 1994 the Bulgarian National Bank excluded from the scope of the credit ceilings only banks' holdings of government securities (Yossifov, 1997, p. 30). The supply of government securities was limited in the early stages of the transition and known in advance to policymakers in Bulgaria.

In what follows, we assume that the unregulated types of banks' earning assets are selected in such a way that the central bank can predict with a high degree of precision their rate of growth that is independent from banks' investments in regulated assets. Furthermore, we assume that the value of the credit ceilings is a positive number, which is consistent with the review of country experiences presented in Farahbaksh and Sensenbrenner (1996, pp. 17-19). Under these assumptions, in order to ensure the stability of the money multiplier and hence the meeting of their monetary or credit targets, as per [5] or [6] respectively, central banks should: (1) set the values of the indirect monetary instruments so that the desired growth rate of the adjusted monetary base is higher than the product of the ratio of unregulated to total banks' earning assets and the rate of growth of the unregulated banks' earning assets that is independent from banks' investments in regulated assets $\left(\frac{\Delta B_{t}^{d}}{B_{t-1}}>\left(1-\beta_{t-1}\right) \cdot \delta_{t}\right)$; and (2) set the value of the partial credit ceilings as per [13]. It should be noted, however, that structural breaks in equation [10] can still destabilize the value of the money multiplier through unexpected changes in the value of $\delta_{t}$. To prevent this from occurring, central banks can impose additional prudential norms on the composition of banks' portfolios.

If the central bank follows the above rules for setting the values of indirect monetary instruments and credit ceilings, the partial derivatives of the credit ceilings with respect to the 
right-hand side variables in [13] imply that other things being equal: ${ }^{7}$ (1) a higher desired rate of expansion of the adjusted monetary base would require a higher value of the credit ceilings to keep the money multiplier stable; (2) a higher rate of growth of the unregulated banks' earning assets that is independent from banks' investments in regulated assets would require a lower value of the credit ceilings to keep the money multiplier stable; (3) the lower the degree of substitutability or the higher the degree of complementarity between the regulated and unregulated types of banks' earning assets, the smaller the value of the credit ceilings that would result in constant value of the money multiplier; and (4) the effect of an increase in the share of banks' earning assets subjected to quantitative controls on the value of the credit ceilings that would keep the money multiplier stable depends on whether the desired rate of growth of the adjusted monetary base is greater, smaller, or equal to the rate of growth of the unregulated banks' earning assets that is independent from banks' investments in regulated assets.

\section{Conclusions}

In this paper, we introduce credit ceilings in the standard model of the money multiplier and analyze their role in central bank management of the money supply in the presence of indirect monetary instruments. We argue that under a regime of joint use of credit ceilings and indirect monetary instruments, the central bank's best strategy is to first adjust the settings of the indirect monetary instruments so as to achieve the desired rate of growth of the adjusted monetary base, and then choose a value for the credit ceilings that will ensure the constancy of the money multiplier (referred below as optimal value).

We then show that under a regime of total credit ceilings, their optimal value equals the desired growth rate of the adjusted monetary base. Under a regime of partial credit ceilings (i.e., quantitative controls that limit the rate of growth of only selected types of banks' earning assets), the central bank's ability to ensure the constancy of the money multiplier via the setting of the credit ceilings depends crucially on the choice of assets left out of the scope of the quantitative controls. In order for the credit ceilings to be effective in monetary management, the regulated and unregulated types of banks' earning assets should

$$
\begin{aligned}
& \frac{\partial c c_{t}}{\partial\left(\frac{\Delta B_{t}^{d}}{B_{t-1}}\right)}>0 ; \frac{\partial c c_{t}}{\partial \delta_{t}}<0 ; \frac{\partial c c_{t}}{\partial \alpha}=\frac{1}{\beta_{t-1} \cdot(1+\alpha)^{2}} \cdot\left[\left(1-\beta_{t-1}\right) \cdot \delta_{t}-\frac{\Delta B_{t}^{d}}{B_{t-1}}\right]<0 ; \text { and } \\
& \frac{\partial c c_{t}}{\partial \beta_{t-1}}=\frac{1}{\beta_{t-1}^{2} \cdot(1+\alpha)} \cdot\left(\delta_{t}-\frac{\Delta B_{t}^{d}}{B_{t-1}}\right) \\
& \left\{\begin{array}{l}
<0, \text { if } \delta_{t}-\frac{\Delta B_{t}^{d}}{B_{t-1}}<0 \\
>0, \text { if } \delta_{t}-\frac{\Delta B_{t}^{d}}{B_{t-1}}>0 \\
=0, \text { if } \delta_{t}-\frac{\Delta B_{t}^{d}}{B_{t-1}}=0
\end{array}\right.
\end{aligned}
$$


not be perfect substitutes, and the growth rate of the latter that is independent from banks' investments in regulated assets should be easily and precisely forecastable. Assuming that, we show that the optimal value of the partial credit ceilings depends on the desired growth rate of the adjusted monetary base, the degree of substitutability between the regulated and unregulated types of banks' earning assets, and the autonomous growth rate of the latter. 


\section{REFERENCES}

Bredenkamp, Hugh, 1993, "Conducting Monetary and Credit Policy in Countries of the Former Soviet Union: Some Issues and Options," IMF Working Paper 93/23 (Washington: International Monetary Fund).

Brunner, Karl, and Allan H. Meltzer, 1964, "Some Further Investigations of Demand and Supply Functions for Money," Journal of Finance, Vol. 19, No. 2, Part 1, pp. 240-83.

Brunner, Karl, and Allan H. Meltzer, 1968, "Liquidity Traps for Money, Bank Credit, and Interest Rates," Journal of Political Economy, Vol. 76, No. 1, pp. 1-37.

Davis, Richard G., 1971, "An Analysis of Quantitative Credit Controls and Related Devices," Brookings Papers on Economic Activity, Vol. 0, No. 1, pp. 65-104.

De Melo, Martha, and Cevdet Denizer, 1997, "Monetary Policy in Transition Economies: An Overview," Policy Research Working Paper 1706 (Washington: World Bank).

Farahbaksh, Mitra, and Gabriel Sensenbrenner, 1996, "Bank-by-Bank Credit Ceilings: Issues and Experiences," IMF Working Paper 96/63 (Washington: International Monetary Fund).

Hilbers, Paul, 1993, "Monetary Instruments and Their Use During the Transition from a Centrally Planned to a Market Economy," IMF Working Paper 93/87 (Washington: International Monetary Fund).

Hodgman, Donald, 1972, "Selective Credit Controls," Journal of Money, Credit and Banking, Vol. 4, No. 2, pp. 342-59.

Johnson, Omotunde, 1974, "Credit Controls as Instruments of Development Policy in the Light of Economic Theory," Journal of Money, Credit and Banking, Vol. 6, No.1, pp. 85-99.

Khatkhate, Deena R., and Delano P. Villanueva, 1980, "Operation of Selective Credit Policies in Less Developed Countries: Certain Critical Issues," in Money and Monetary Policy in Less Developed Countries: A Survey of Issues and Evidence, ed. by Warren L. Coats and Deena R. Khatkhate (Oxford and New York: Pergamon Press), pp. 589-603.

Mathieson, Donald J., and Richard D. Haas, 1994, "Establishing Monetary Control in Financial Systems with Insolvent Institutions," IMF Paper on Policy Analysis and Assessment 94/10 (Washington: International Monetary Fund).

McCallum, Bennett T., 1989, Monetary Economics: Theory and Policy (New York: Macmillan Publishing Company). 
Mishkin, Frederic S., 1997, The Economics of Money, Banking, and Financial Markets (Reading, Massachusetts: Addison-Wesley, 5th ed.).

Rasche, Robert H., 1993, "Monetary Policy and the Money Supply Process", in Monetary Policy in Developed Economies, Handbook of Comparative Economic Policies, Vol. 3, ed. by Michele U. Fratianni and Dominick Salvatore (Westport, Connecticut, and London: Greenwood Press), pp. 25-54.

Simmons, Edward, 1947, "The Role of Selective Credit Controls in Monetary Management", American Economic Review, Vol. 37, No. 4, pp. 633-41.

Yossifov, Plamen K., 1997, Selective Credit Controls and the Money Supply Process in Transitional Countries: The Case of Bulgaria, Master's thesis, University of Delaware (http://udel.edu/ pyosifov/papers.html). 